\title{
MATEO DE PRADO EN EL MONASTERIO DE CONXO
}

\author{
por RAMON OTERO TÚÑEZ
}

Ante la reciente atribución al gran escultor José Ferreiro de la escultura de San Andrés del monasterio de Conxo, en Santiago de Compostela, se precisa que dicha imagen y la de San José son un siglo anteriores y, apoyándose en los datos documentales existentes y el análisis formal y estilístico de ambas obras, se consideran hechas por Mateo de Prado, el discípulo de Gregorio Fernández, que trabaja en Compostela en el segundo tercio del siglo XVII. Ejemplares, pues, antológicos del mundo barroco y de ninguna manera del neoclásico.

In view of the recent attribution of the sculpture of St. Andrew in the monastery of Conxo, in Santiago de Compostela, to the great sculptor José Ferreiro, it is argued in this article that the images and of St. Joseph are a century earlier and, on the basis of existing documentary data and a formal and stylistic analysis of both sculptures, that they are the work of Mateo de Prado, a pupil of Gregorio Fernández who worked in Compostela in the second third of the 17th century. They are therefore perfect representatives of the Baroque world and in no way neoclassical.

Hace muchos años, cuando preparaba mi tesis doctoral sobre la imaginería en Compostela, intuí la posibilidad de que las esculturas de San José y San Andrés de la iglesia conventual de Santa María de Conxo fuesen talladas por Mateo de Prado. El análisis comparativo de sus formas con las de algunas obras documentadas del artista me confirmó no sólo tal hipótesis, sino también la de encontrarme ante dos figuras pertenecientes a los últimos años de tan representativo discípulo de Gregorio Femández 1.

1. OTERO TUÑEZ, R.: Escultura. El barroco y el rococó. "Historia del arte hispánico". IV. Madrid, Segunda reimpresión, 1989, 155. 
Por otra parte, acomodados a las necesidades de la iglesia, tras la reconstrucción barroca, se conservan más o menos recompuestos dos retablos del siglo XVII, que parecen haber servido para alojar a ambas imágenes. Uno acoge todavía la de San José. Elementos del otro se aprovecharon en el de la Beata Mariana de Jesús, ya de época neoclásica. Sus columnas salomónicas, de espirales muy pronunciadas y recubiertas por hojas y racimos de uvas, evocan muy de cerca las más antiguas de la capilla mayor de la catedral compostelana ${ }^{2}$ y las de algunos retablos donde consta la colaboración o participación de Mateo de Prado 3. Otras columnas, también salomónicas y con vides, flanquean el único sagrario conservado, cuya puerta muestra un relieve del Salvador, de estructura y talla vinculables al mismo taller que esculpió el coro de San Martín Pinario ${ }^{4}$.

Así las cosas, pedí a don Francisco Asorey su opinión de escultor y buen conocedor de las técnicas y recetas plásticas de nuestros talleres barrocos. Juntos visitamos el templo mercedario, donde el gran artista obtuvo un vaciado de la cabeza de San Andrés, hizo varios dibujos de partes significativas de ambas imágenes y palpó con sus dedos pliegues y oquedades de los ropajes hasta descubrir la dirección y corte de los gubiazos. Tras analizar los resultados y cotejarlos con esculturas de su propiedad, procedentes del desmontado retablo del convento de Vistalegre de Vilagarcía de Arousa, contratado ${ }^{5}$ por Mateo de Prado en 1642, me notificó pocos días después su asentimiento a la atribución de las esculturas de Conxo al mismo escultor.

Varios años después, la memoria de licenciatura de don Alejandro Barral 6 aportó interesantísimos datos, fruto de una exhaustiva rebusca entre los documentos procedentes del antiguo monasterio de Conxo. Tres nos interesan ahora fundamentalmente: a) Según el "Libro de recibo y gasto de capitales", Fr. Andrés Fortes promovió la construcción de la "sillería del choro, órgano y... los dos retablos colaterales al mayor". b) Las obras deben fecharse entre 1664 y 1673, años en los que el mecenas Fortes tuvo relación con el monasterio, cuya iglesia

2. OTERO TUÑEZ, R.: Unos planos inéditos del archivo de la catedral de Santiago. "Cuadernos de Estudios Gallegos", 1951, 220 y ss. BONET CORREA, A.: La arquitectura en Galicia durante el siglo XVII. Consejo Superior de Investigaciones Científicas. Madrid, reimpresión de 1984, 266-67.

3. FERNANDEZ GASALLA, L.: La autoría del retablo de Montederramo: Bernardo Cabrera y su hijo Juan de Cabrera, retablistas del escultor Mateo de Prado. "Brigantium", 6, La Coruña, 1989-1990.

4. ROSENDE VALDES, A.: La sillería de coro de San Martín Pinario. La Coruña, 1990, 272.

5. PEREZ COSTANTI, P.: Diccionario de artistas que florecieron en Galicia durante los siglos XVI y XVII. Reimpresión Xunta de Galicia. Santiago, 1988, 453.

6. BARRAL IGLESIAS, A.: Monasterio de Santa María la Real de Conxo. Memoria de licenciatura, 1992, 145-151. Diputación Provincial de La Coruña.. 
era aún la románica; así ambos retablos estarían colocados en los dos ábsides menores; y uno de ellos dedicado al santo patrono del fraile mercedario. Y c) Por el "Libro de misas perpetuas de fundaciones" sabemos además que todavía en 1787 seguían aplicándose sufragios por los artistas que trabajaron generosamente para los mercedarios compostelanos: Gregorio Fernández, autor del famoso Cristo; Mateo de Prado, de las imágenes a que ahora nos referimos; y Diego Romay, de la iglesia nueva o parte de ella.

Pese a todo ello, una reciente publicación ${ }^{7}$ atribuye la talla de San Andrés al patriarca de la escultura neoclásica gallega, José Ferreiro. Después de lo dicho tal hipótesis carece de sentido y no necesita más comentario.

Presentemos, pues, ambos santos dentro de su contexto seiscentista, en íntima conexión con toda la plástica del norte peninsular, siempre bajo el influjo de Gregorio Fernández.

El culto y presencia de la imagen de San José en la iglesia de Santa María de Conxo ha de explicarse dentro de la exaltación josefina que se aprecia a partir del siglo XVI. Ya en 1522, Isidoro de Isolano había anunciado que "el vicario de Cristo en la tierra, por inspiración del Espíritu Santo, mandará que la fiesta del padre putativo de Jesús, del esposo de la reina del mundo, del hombre santísimo, se celebre en todos los confines del-imperio de la Iglesia militante. Y así el que en el cielo siempre estuvo delante, no estará en la tierra detrás" 8 .

Dos décadas después, Santa Teresa le atribuía la curación de la parálisis que la había mantenido sin poder andar durante tres años ${ }^{9}$; y el 24 de agosto de 1562 fundaba el convento de San José de Avila, para cuya fachada esculpió Giraldo de Merlo, dentro de la primera década del siglo XVII, la magnífica figura que la preside 10 .

Esta imagen de San José y la poco anterior del monasterio de Guadalupe, hecha por Antón de Morales "1, inauguran en la escultura española una iconografía del santo como protector y guía de Jesús niño, que camina a su lado. El "tipo" es aceptado y consagrado definitivamente por Gregorio Fernández ${ }^{12}$, cuyos seguidores lo mantienen hasta bien entrado el siglo XVIII.

7. MARIÑO, X.X.: O escultor Ferreiro. Noia, 1991, 28.

8. LLAMERA, B.: Teologia de San José. Biblioteca de Autores Cristianos. Madrid, 1953, 545 46.

9. AUCLAIR: Vida de Santa Teresa. Madrid, 1970, 30 y ss.

10. RAMIREZ DE ARELLANO: Giraldo de Merlo. "Arte español”, 1914-15, 253.

11. BUSTAMANTE GARCIA, A.: Juan Muñoz escultor. "Boletín del Seminario de Arte y Arqueología". Valladolid, 1973, 269 y ss.

12. URREA, J.: Dos San Josés ignorados de Gregorio Fernández. "Estudios Josefinos", 59, 1976, 71. MARTIN GONZALEZ, J.J.: El escultor Gregorio Fernández. Madrid, 1980, 220-23, láms. 198-200. 
Y así es la talla compostelana. El patriarca se inclina hacia la derecha para coger de la mano al niño, mientras apoya su izquierda en la vara florida, que lo señaló como el adecuado esposo de la Virgen, según narra el "Libro sobre la natividad de María" 13: "El sumo sacerdote se acercó para consultar a Dios. Y al momento se dejó sentir en los oídos de todos una voz proveniente del oráculo y del lugar del propiciatorio. Decía esta voz que, en conformidad con el vaticinio de Isaías, debía buscarse alguien a quien se encomendase y con quien se desposase aquella virgen. Pues es bien sabido que Isaías dice: Brotará un tallo de la raíz de Jesé y se elevará una flor de su tronco... De acuerdo, pues, con esta profecía, mandó que todos los varones pertenecientes a la casa y familia de David, aptos para el matrimonio y no casados, llevaran sendas varas al altar. Y dijo que el dueño de la vara, que una vez depositada hiciera germinar una flor y en cuyo ápice se posara el Espíritu del Señor en forma de paloma, sería el designado para ser custodio y esposo de la Virgen... Esto patentizó bien a las claras que era él con quien debía desposarse". El rostro de la imagen, a un tiempo enérgico y ensoñador, refleja la paternidad asumida del santo sobre el hijo de María. Su espesa cabellera, tupé sobre la frente y barba resuelta en bucles acaracolados evidencian, por otra parte, la mano de Mateo de Prado, la cual se manifiesta también en las oquedades y cortes acartonados de la indumentaria de nuestro personaje y en la del niño acompañante, ésta retocada y repintada. Viste el patriarca túnica y manto. Aquella, relativamente corta para permitir la visión de las botas, nuestra una abertura ante el pecho, se ciñe sobre la cadera mediante un cinturón que determina la caída de esos pliegues característicos de la escuela y destaca entre su tonalidad verde rica policromía a base de volutas estofadas en oro y flores rojizas trazadas a punta de pincel. El manto, con su cuello visible sobre el hombro derecho, mientras el borde inferior del lado opuesto se despliega desde el izquierdo, deja aflorar también, a través de una coloración ocre acastañada, menudos y múltiples motivos vegetales o geométricos, cuya retícula contribuye al efecto de vistosa joya que proporciona la escultura.

Todavía más espectacular y representativa del barroquismo seiscentista es la imagen de San Andrés, el patrono de Fortes, quien, antes de su marcha definitiva a América en 1673, quiso honrarlo donando para el culto la singular talla, como ya he indicado. Lo representa fundido conceptual y compositivamente con la cruz de aspa, atributo del santo, que padeció el martirio atado a ella, por orden del prefecto Egeas, según refiere la "Passio sancti Andreae apostolo" 14. Apoyando la mano derecha y el pie izquierdo sobre las protuberancias de dicho

13. SANTOS OTERO, A.: Los evangelios apócrifos. Sexta ed. Madrid, 1988, 247-48.

14. HOPHAN, O.: Los apóstoles. Barcelona, 1957, 89-98. 
instrumento de suplicio y sosteniendo la siniestra un libro, símbolo común de todos los apóstoles de Cristo ${ }^{15}$, la espléndida figura acusa enseguida ser de la misma mano que el San José: espesa cabellera con tupé, cuello del manto sólo visible por uno de los lados, túnica abierta dejando al descubierto el pecho, pliegues acartonados o en forma de láminas metálicas y policromía imitando suntuoso brocado. Un extraordinario virtuosismo técnico, animado por encarnación de paletilla, subraya la enérgica virilidad de las manos, la vitalidad del pecho y la profunda expresividad del rostro, con la boca entreabierta, mostrando dientes y lengua. Los bordados vegetales en oro y las grandes flores en tonos blancos, rojos, rosas y azules iluminan los colores simbólicos de túnica y manto, verde y sangre, respectivamente, que aluden al martirio de San Andrés. El efecto barroco del conjunto se hace así antológico.

15. MALE, E.: El gótico. La iconografia de la Edad Mediad y sus fuentes. Madrid, 1986, 315. 


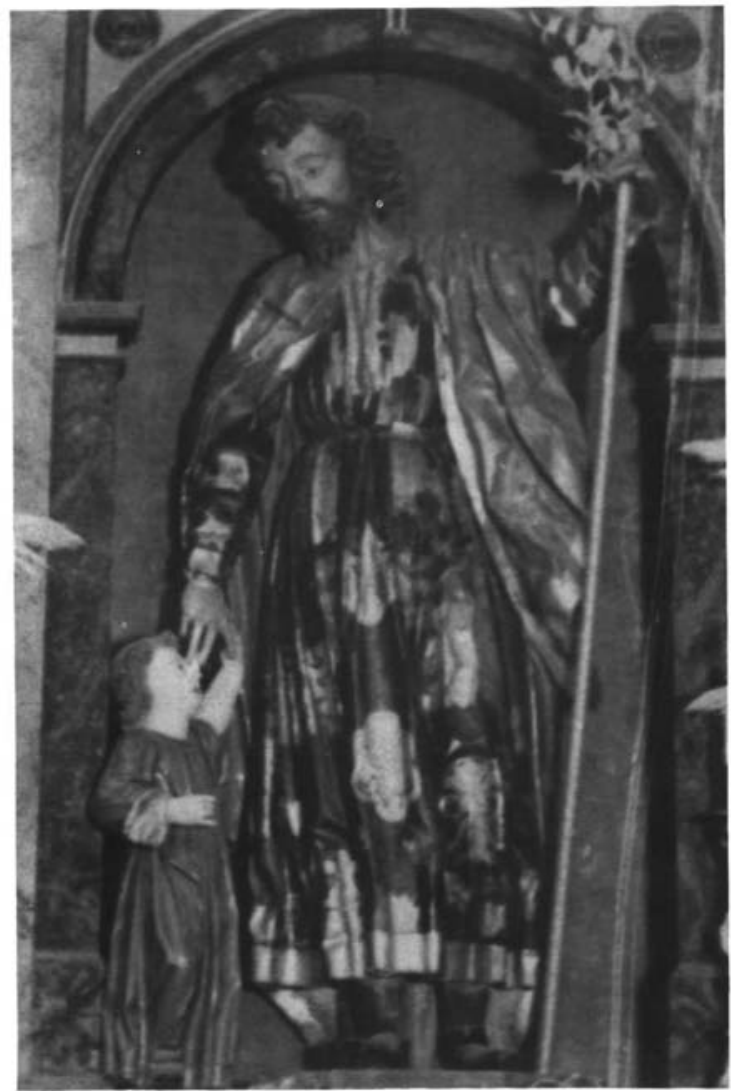

MATEO DE PRADO: San José.

Santa María de Conxo. (Foto Ksado). 


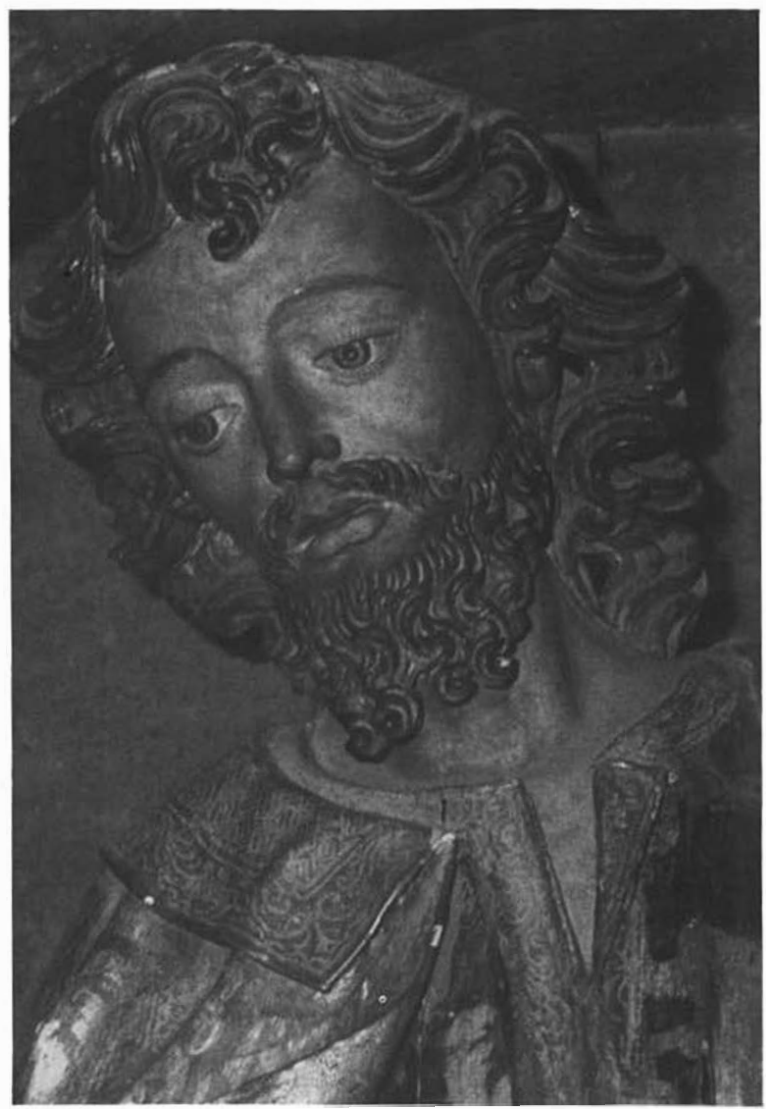

MATEO DE PRADO): Cahe zude San Jnsé.

Santa Maria de Conxo. (Foto Kudo). 


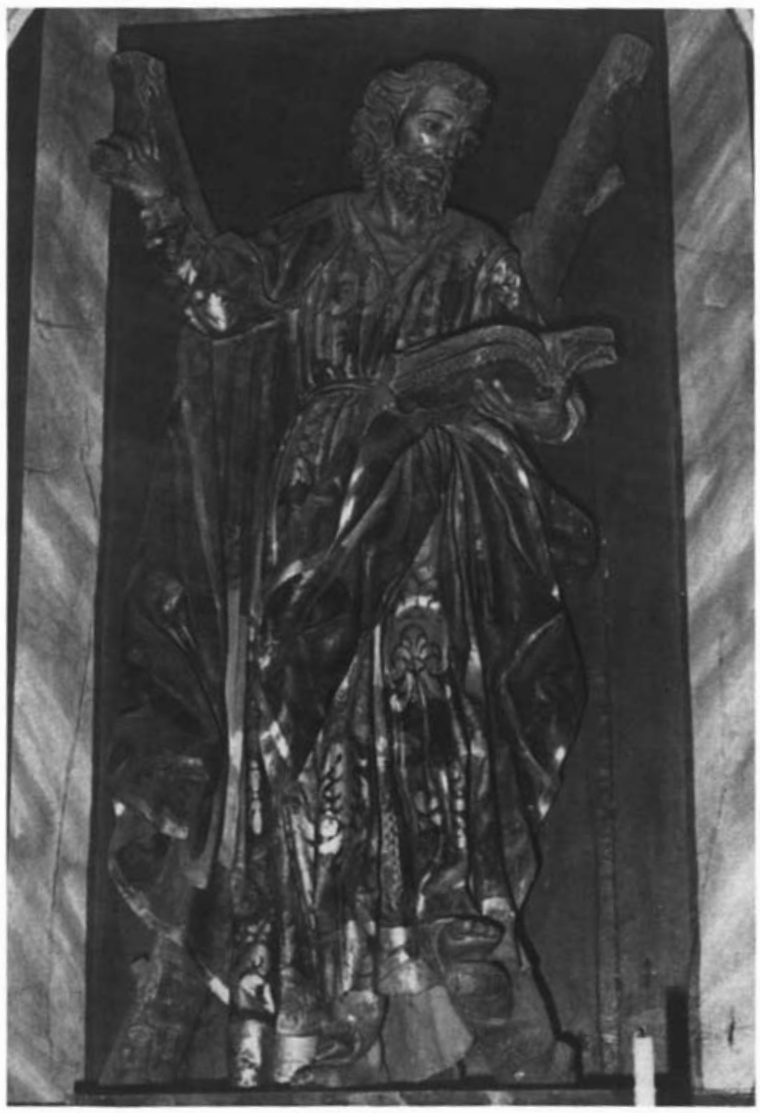

MATEO DE PRADO: San Andrês.

Santa María de Conxo, (Foto Ksado). 


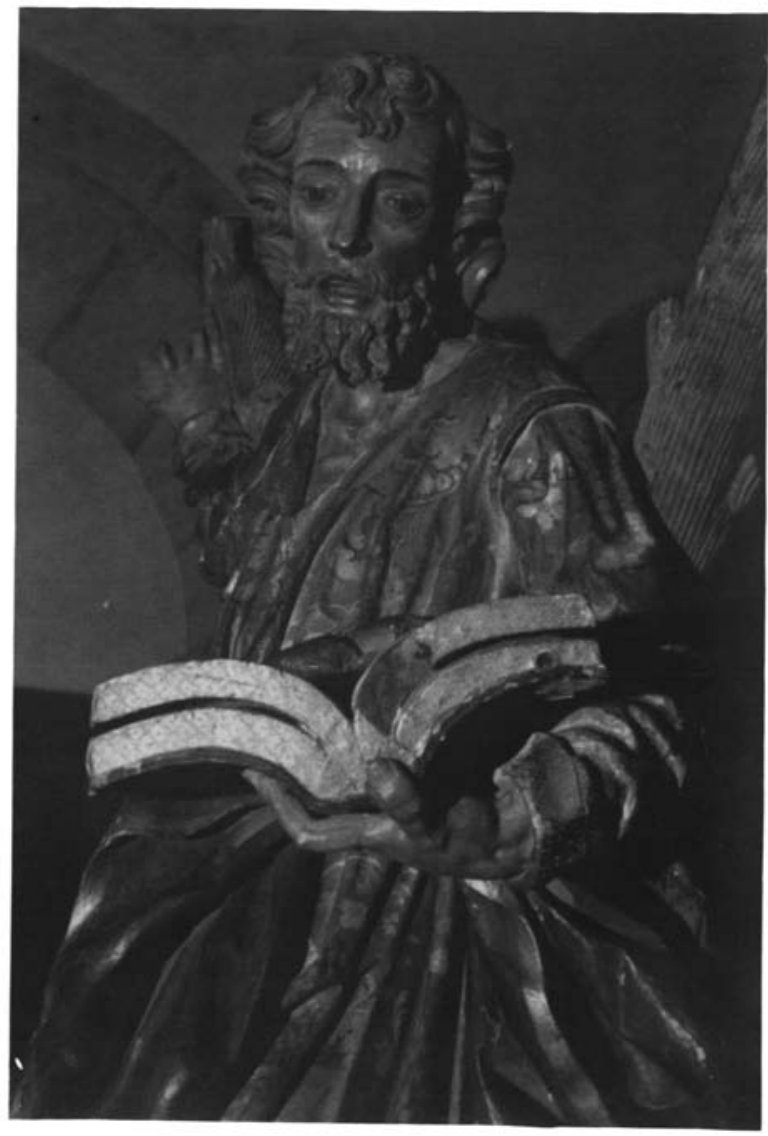

MATEO DE PRADO: San Andrés (detalle).

Santa María de Conxo. (Foto Ksado). 